\title{
Un Esprit Démocratique: les dérives de Lejeune, chiffonnier et collectionneur des autobiographies
}

\author{
T. G. Ashplant
}

\section{ENCOUNTERING LEJEUNE: "MOI AUSSI"}

My university career began in the mid-1980s, in a department then pioneering interdisciplinary teaching of history and literature. The "theory revolution" in literary studies was at its height, and to some of its more fervent proponents the discipline of history seemed irremediably naïve. Historians, it was asserted, were in the grip of an illusion: they believed in the existence of a world outside the text, whose past could be recovered, and straightforwardly represented in prose modelled on a form-the realist novel-then subject to hostile critique. It is true that (Anglophone) history as a discipline, rooted in the profound empiricism of the archive, had a deep aversion to any form of theoretical reflection on its own practice. Only gradually over the next thirty years would diverse influences-including (but not limited to) Hayden White's insistence on the embeddedness of interpretation within textual forms, feminist theorising of the structural silences of gender regimes, oral history's exploration of the obliquenesses of meaning within narrative, and the problematisation of the present/past relationship within memory studies-prompt historians towards a more complex understanding of the implications of the textual bases of their profession. Nevertheless ... some of the theory-driven criticism seemed itself equally naïe, based on an ignorant caricature of what historians actually thought and did. So, when I was preparing a course on Autobiography-as a topic well suited to interdisciplinary teaching - it was a welcome pleasure to encounter the work of a literature scholar in full command of the analytical and theoretical skills of their discipline, who nevertheless approached life-writing texts in ways cognate to those of a historian. 
It was in this context that I read with enthusiasm Philippe Lejeune's two essays "The Autobiography of Those Who Do Not Write" and "Autobiography and Social History in the Nineteenth Century." Here was a literary scholar who had engaged with key canonical texts (Rousseau, Stendhal, Gide, Sartre, Leiris), and yet who widened the scope of his vision to the entire field of autobiographical writing. These essays display, in microcosm, two distinct stances towards life writing which have animated Philippe's prolific career. In one corner stands the scholar who extracts all possible riches from his key notion of the "autobiographical pact," a contract between author and reader as to how a text should be read. ${ }^{2}$ In the first part of "The Autobiography of Those Who Do Not Write"-an apparent impossibility-he seizes on a controversy over the authorship of a ghost-written autobiography as an ideal opportunity to unpack the manifold complexities of the relationships in life writing between model, author and reader. He unfolds a dialectical argument, which frequently turns back on itself to contradict a formulation no sooner made than seen as inadequate, so as to unpick the power relations at work in the creation, publication and reception of an autobiographical text. ${ }^{3}$ He finds it necessary to expand on this tripartite relationship to include also the publisher. In addition-and this is where a literary-theoretical perspective combines fruitfully with a historico-sociological one-he underlines the power of form in shaping what it is possible to write and to read in a particular era. Though the argument is complex and sinewy, it is presented with a lightness of touch and tone heightened at times by a sharp humour. ${ }^{4}$

But besides that of the detached scholar savouring the nuances of definition and analysis, there is another stance which becomes apparent in both the second part of this essay and its companion: that of the omnivorous enthusiast who devours life writing in its many forms. Philippe himself has engaged in several such forms at different stages of his life. He kept a diary from the age of fifteen for about ten years, although reading Proust led him to give up his wider literary ambitions in despair. At thirty he revived these efforts by creating a writing workshop for himself (and later still he would resume diary writing). ${ }^{5}$ Increasingly, life narrative became not only the object of his research, but the (self-reflexive) mode of its presentation, as in his many articles which take the form of a research diary. ${ }^{6} \mathrm{He}$ later participated in Vincent de Gaulejac's laboratory of clinical sociology, responding to the question how his life story and theoretical choices were interconnected-an experience of which he wrote: "Not only did it make me feel like a lab animal, but I was required to dissect myself into the bargain."7

In the same year that Lejeune resumed his abandoned literary efforts-1968 with its momentous cultural upheavals-he experienced a shift of perspective which would shape his future career. Whereas 
previously " [i] t never occurred to me that research could leave the beaten tracks. One had to be canonically correct at that time," he now discovered "a vast uncharted territory, uncharted because it was despised, a territory of fabulous wealth: autobiography." At first, his work in this field focussed on its (few) canonical works. But then two rather different encounters provoked a further shift: the difference between the "disarmed and disarming" Sartre seen in the film Sartre par lui-même (1976) and "in complete contrast ... the seductive artfulness of Les Mots" (1963); and (nearer to home) the life writings of a family member, his great-grandfather XavierEdouard (1845-1918), a shop assistant in the new department stores of mid-nineteenth century Paris. ${ }^{8}$ This text he had thought "touching, but conventional and flat, until I discovered that my great-grandfather had lied about the most important facts of his life, and the easiest to check, his birth and marriage." Whereupon Lejeune embarked on the first of many forays into the public archives, "unravelling a text which I had naively thought to be naïve." Out of this encounter came the recognition that: "The trouble with studies of personal writings is that critics focus their attention on the few published works that have met with success and have survived, whereas autobiography is not primarily a literary genre, but first and foremost a widely spread practice ...." Lejeune's attention now broadened to embrace not only the limited canon of 'literary' autobiography, but a much wider field of life writing. He "decided to undertake a complete inventory of the autobiographies written in France from about 1789 to 1914" - no less! — with the intention of writing "a sort of "social history of discourses". ${ }^{9}$ Autobiography, he asserted, "is not primarily a literary genre, but first and foremost a widely spread practice;" hence:

it was no longer a matter of reasoning on the basis of unique masterpieces but on a series of texts displaying the whole range of ways in which, in a given situation, you can represent your life. It was also a matter of dealing with these texts as historical facts in their own right, contrary to historians who tend to exploit them as sources of information on other subjects. ${ }^{10}$

This second, and much bolder, step across the borders of the literary was met with some incredulity.

It is difficult to tear onself away from an intellectual training. And then literature is full of charm, I like writing. To relativise literature was a gesture against nature. ... That the autobiographical act is not considered as specifically literary shocked more than one [university colleague]: I was often asked where, for me, literature ended. ${ }^{11}$

Looking back in 2002, Lejeune would write: 
From that period [the later 1970s] date what certain of my university colleagues call my 'deviations' ['dérives'], as if I took part in a terrorist movement threatening literature. On the contrary, it seems to me that it has expanded its domain. ... I am passionate about ordinary writings. I have not 'deviated,' I have widened my horizons (“Tout lire," 187).

The importance of Lejeune's insistence on the value of 'ordinary writings'-which has analogies with Raymond Williams's insistence on the category of "writing" as a democratic alternative to that of literature-is explored in various ways in the contributions to this festschrift by Arianne Baggerman and Rudolf Dekker, Thomas Couser, Christa Hammerle, and Gillian Whitlock.

\section{LEJEUNE'S PROJECT: “TOUT LIRE”}

In the course of compiling his inventory on nineteenth-century autobiographies, based on the call number Ln 27 in the Bibliothèque Nationale (which covers individual biographies), Lejeune wrote that: "There are more than 90,000 works cataloged under this call number. I actually went through 63,000 entries. And I am presenting to you 23 industrial or commercial life stories. The yield is low, but that is the price of any historical work" $(O A, 165)$. What beleagured historian's heart would not warm, as mine did then, with rueful but grateful recognition on reading these words! From this decision came a series of studies of the published autobiographies of employers and schoolteachers, and then the archivallysourced lives of criminals and homosexuals. ${ }^{12}$

Philippe offers a striking-and democratic-image of his developing role in the 1970s: where once he would have tried to pluck out with a pair of tweezers-from the jumble ("fatras") of autobiographical writingssome passable texts which fitted literary norms and were sufficiently elitist, now as a rag dealer ("chiffonnier") he threw himself into this rubbish heap ("poubelle") to nose around ("fouiner"), and select ("trier"). "What I like, in this chiffonnier's work, is the human contact." After a day in the library, reading a dozen texts, "I come out in the evening having encountered a dozen existences, a dozen destinies who did not know each other but who have left traces whose reading has transformed me into a unanimist novelist." This encounter is not only pleasurable, but instructive: he learns as a historian, because these texts are revealing of social practices and mentalities; and as a literary scholar, because their absence of elaboration, often their brevity, makes it possible to study the 'basic forms' which enter into the composition of an autobiography ("La cote Ln 27," 257-258). 
In the summary account of businessmen's autobiographies in On Autobiography (166-184), Lejeune was already combining study of circulation and textual form with that of authorship. These investigations were the start of a process in which he would turn his attention to increasingly diverse forms of life writing (and more broadly life narrative) from nineteenth-century girls' diaries to radio interviews to blogging. ${ }^{13}$

His work on his great-grandfather's text helped Lejeune to grasp "what is so fascinating in ordinary autobiography: it requires a more active involvement from the receiver than literary autobiography." 14 This insight bears on a problem which has long impeded productive exchanges between literary scholars and historians about how to read non-elite life writings: the inappropriateness of conventional literary criteria had led to an inability to engage with the structure of such writing, and hence their dismissal as unable to offer anything of value as texts/narratives in understanding how their authors made sense of their lives.

Such an inventory is inevitably precariously balanced between the expectations of literary history and those of social history .... I am offering ... the possibility of knowing the civilization of the nineteenth century in the way that its participants saw it .... I look at these autobiographical texts not as documents containing information about the author (information that could, if necessary, be obtained elsewhere), but as social facts in themselves, in their reality as texts $(O A, 165)$.

It is striking how early Lejeune had reached such an interdisciplinary understanding of how to engage with life writings, one which has still not been fully grasped and utilised. His entire oeuvre tracks back and forth across the conventional borders of literary and historical study, complicating and deconstructing each (see further below).

\section{DEMOCRATIC CREATIVITY: "SIGNES DE VIE”}

A third, linked dimension of Lejeune's stance towards life writing demonstrates most fully both his democratic spirit, and his social inventiveness. ${ }^{15}$ His publications, and broadcasts appealing for unpublished nineteenthcentury manuscript autobiographies, had led to his receiving-unsolicited-many contemporary texts. ${ }^{16}$ Soon unable to respond to so many correspondents personally, he was inspired to create in 1992, together with Chantal Chaveyriat-Dumoulin, L'association pour l'autobiographie et le patrimoine autobiographique (L'APA). With the support of the mayor and the municipal library of Ambérieu-en-Bugey (now designated "Ville de l'autobiographie"), an archive was established to which all forms of 
unpublished life writings could be donated; to date, these total nearly 3,500 ("Tout lire," 183-186).

In discussing his work on family history, Lejeune had already asserted that "the important thing is this, living memory ... the memory of the archives is a dead memory;" hence the genealogist-archivist must use mouth-to-mouth resuscitation to give this memory some life, some presence ("En famille," 186). This perception helped shape the great creative originality of L'APA: that it is not simply an inert archive, a repository (however valuable) of texts many of which would inevitably remain untouched, unread. Instead, its genius lies in the reciprocal relationship it establishes between author-depositors and the association-in the form of its readers' groups ( groupes de lecture). ${ }^{17}$

The members of each group take on the task of reading each text assigned to them, and preparing (in addition to standard bibliographical details) a responsive reading (écho), which-after agreement with the author-depositor-is then posted in the online catalogue (and later published in the annual Garde-mémoire). ${ }^{18}$ This achieves two goals. The catalogue contains a synopsis of the text, which is valuable for researchers. But, as importantly, it enables the author-depositor to know that their work has received a thoughtful, collectively considered and agreed, reading (lecture en sympathie).

Lejeune has given a detailed and lively account of the workings of such a groupe de lecture, and of what is implied by a lecture en sympathie. ${ }^{19}$ The groups share a common and carefully worked-out set of procedures, into which new group members are initiated when they join. The aim is to ensure that each text receives a sympathetic reading, without judgment, without risking "a lukewarm or hurtful response" (51). This is possible because the group members between them have different sensibilities and expectations, so that "the texts are distributed according to our affinities: in some way, it is the texts that select us!" (52).$^{20}$ The écho is a sketch rather than a synopsis, which aims "to evoke the tone, the method of the text, its main lines and what is at stake" (54). ${ }^{21}$ Lejeune also points to the creative exchange between readers and author which may sometimes develop subsequently. ${ }^{22}$ The omnivorous aspect of Lejeune's desire "tout lire" issues in the fantasy of creating a unanimist novel à la Jules Romains. But it is balanced by the recognition that no-one can read everything with sympathy ("Tout lire," 190). Hence the creation of the groupes de lecture. The democratic aim to read everyone's story can only be achieved by the democratic method of collective reading.

L'APA has also given birth to two further collective activities. It has remained alert to the danger that, after its initial lecture en sympathie, a text-once deposited-may nevertheless become inert within the archive. 
Hence the formation of re-reading groups (groupes de relecture); these come into being for a period of two or three years to select and re-read texts from the archive around a particular theme. Each issue of L'APA's triannual, La faute à Rousseau: Revue de l'autobiographie, combines such rereadings with short original texts, or introductions to or extracts from published works, on a specific theme (most recently, "Loss" and "Exile"). The result is that, in Philippe's words: "Our archive seems more and more like a sort of 'unanimistic novel,' or collective autobiography, representing in all its facets French society of the twentieth century" (62). ${ }^{23}$

In addition, some nine groupes locaux, which between them sustain a range of activities related to the cherishing and promoting of life writing, have also been created over the past twenty-five years. The work of these groups then form the thematic issues of the series Cahiers de l'APA. Among the 65 publications to date, such themes have included "Writing the Body," "The 'I' at Work," and "Writing your war, 1914-1918." A group has been recently working on the theme of "May 68 and its aftermath," in preparation for the fiftieth anniversary of the May events.

The formation of the L'APA can be situated in a wider international context. In the $1980 \mathrm{~s}$ and $90 \mathrm{~s}$, several countries saw the creation of archives devoted to various forms of non-elite life writing and life narration which would otherwise be lost (or not brought into being). The national motivations were diverse (responding to different political, social and educational histories). But there were nevertheless cognate aims and shared inspiration. ${ }^{24}$ Lejeune has noted that he was inspired by the Fondazione Archivio Diaristico Nazionale (National Diary Archive Foundation), in Pieve Santo Stefano, Italy, founded in 1984 ... while recoiling from its practice of awarding a prize. "A competition among autobiographies! I was slightly shocked when I first attended the final and vowed I would never do such a thing." ${ }^{25}$ L'APA in its turn has become an inspiration for others, an exemplar of how scholarship can reach out beyond the boundaries of the academy, and establish a dialogue with the wider society.

To return to the specificity of non-literary autobiographies. It is ironic for me to read Philippe's lament about the researchers who visit L'APA's archive in the municipal library La Grenette at Ambérieu.

\footnotetext{
Very often foreigners - as if French researchers, saturated with more classic 'sources,' had less curiosity or receptivity. Almost always sociologists or historians. This means, even if they are focused on the history of mentalities, they will tend to be more sensitive to the information given by our texts on everyday life and private practices than to the text itself as expression and creation.
} 
From the literary scholar there then comes a heartfelt cri-de-coeur: "When will we see a disciple of Gérard Genette or Paul Ricoeur arrive, curious to test on hundreds of 'ordinary' texts the analyses based on the reading of a smaller number of prestigious works?" ${ }^{26}$ Such are the continuing difficulties of interdisciplinary research, across borders both of discipline and canon, which Lejeune's work has done so much to enable theoretically, to facilitate and promote practically. In addition to his varied self-descriptions as a collector, a maker of inventories, and a chiffonnier, Philippe has also positioned himself as an outsider. ${ }^{27}$ One might extend this last designation: is he not a passeur, a smuggler who crosses the borders between disciplines (psychoanalysis, sociology, ethnonology and oral history, as well as literature and history) ${ }^{28}$ Who, instead of paying (canonical) duties, brings to each domain valuable contraband from another? These smuggled goods include the defining of both autobiography and diary as not simply texts, but the products of (different) social practices; the de-essentialising of genres as always historically constituted; the use of genetic studies as a way of historicising the texts of autobiographies and diaries, thereby rescuing them from the limitations of traditional historical "source criticism"; the emphasis on autobiographies and diaries as texts produced within social discourses, which can be read in much richer ways than simply as 'sources' of 'facts'; the role of archival research on manuscripts as a way of recontextualising canonical 'literary' texts; and the value of revealing the role of one's own subjectivity in shaping one's (always provisional) research findings. ${ }^{29}$

\section{READING LIFE WRITINGS: "JE EST UN AUTRE”}

The low and the high, the rudely secular ("gourmandise de chiffonnier": "Le cote Ln 27," 258) and the quasi-sacred, commingle in the Lejeune oeuvre. The great value which Philippe accords to words can be glimpsed in the occasional use which he, "si agnostique," makes of a strong religious image-as when a meeting of the groupe de lecture to which he himself belongs is described as: "a common meal, with simple dishes, a sort of mystical 'Supper.' 'Take, for this is life"” ("Lire en sympathie," 49). Of course, as ever, his tone is at once ironical and self-mocking. ${ }^{30}$ Nevertheless, the suspicion remains: might this irony be one of his "strategies of evasion," "hiding behind screens"? ("En famille," 181) Here too-in this passionate but wary approach to the notion that "In the beginning was the Word"there is a connection with, and a warning for, the historian. One of the functions of history writing is to make the actions and words of people in the past available as a resource in and for the present: to destabilise its fixedness, its apparent inevitability, by showing the multiple impulses 
which have given rise to it-some of which have been thwarted or are as yet unfulfilled. ${ }^{31}$ Philippe's reflections on his experience of writing family history offer a valuable, and typically self-interrogating, word of caution. "Why does one read life writings? Altruism, desire to listen to each other, ethnological curiosity?" Yes, but ... he has been more struck by the opposite: "one reads life writings to construct one's own identity: reading autobiographies is a fitting room for roles. Here too there is a contradiction between the avowed motivations (knowledge of the other, listening to voices which have been ignored, etc) and the strongly egocentric reality" ("En famille," 198). Just as much as the collecting and valuing of the texts in which such voices now reside, the formation of reading groups, with their democratic interplay of different perspectives which Philippe celebrates, might be seen as a creative response to this recognition. ${ }^{32}$

Écrire sa vie_lire les récits de vie des autres_c'est partager sa propre vie.

Bon anniversaire, Philippe!

\section{WORKS CITED}

Iuso, Ana. "The Role and Impact of the Archivi Della Scrittura Popolare." Journal of Modern Italian Studies 19.3 (2014): 241-251.

Lejeune, Philippe. "L'autobiographie de ceux qui n'écrivent pas." In Je est un autre, 229-316. Lejeune, Philippe. "Autobiographie et histoire sociale." Revue de l' Institut de sociologie, nos 1-2 (1982): 209-234 (Répertoire des autobiographies écrites en France au XIXe siècle, Section 1, "Vies commerciales, industrielles et financières," 226-234).

Lejeune, Philippe. "Autobiographie et homosexualité en France au XIXe siècle." Romantisme n 56 (1987): 79-100 (Répertoire des autobiographies écrites en France au XIXe siècle, Section 4, "Vies d'homosexuels," 95-100).

Lejeune, Philippe. "Cher cahier ...”: témoignages sur le journal personnel. Paris: Gallimard, 1990. Lejeune, Philippe. "Cher écran ...." Journal personnel, ordinateur, Internet. Paris: Seuil, 2000.

Lejeune, Philippe. "Crime et testament. Les autobiographies de criminels au XIXe siècle," Cahiers de sémiotique textuelle, $\mathrm{n}^{\circ}$ 8-9 (1986): 73-98 (Répertoire des autobiographies écrites au XIXe siècle, Section 3, "Vies de criminels, 1. 1789-1880," 87-98).

Lejeune, Philippe. "Du brouillon à l'oeuvre," In Écrire sa vie, 67-76.

Lejeune, Philippe. Écrire sa vie. Du pacte au patrimoine autobiographique (Paris: Éditions du Mauconduit, 2015).

Lejeune, Philippe. "En famille." In Moi aussi, 181-202.

Lejeune, Philippe. "Ethnologie et littérature: Gaston Lucas, serrurier." In Moi aussi, 273-291.

Lejeune, Philippe. "From Autobiography to Life-Writing, from Academia to Association: A Scholar's Story." www.autopacte.org/From\%20Academy\% 20to\% 20Association.html [accessed 3.2.18].

Lejeune, Philippe. "Genèse de Nous autres à Vauquois." www.autopacte.org/Accueil_7.html [accessed 3.2.18].

Lejeune, Philippe. "Itinéraries d'une recherche." In Écrire sa vie, 13-35.

Lejeune, Philippe. Je est un autre: l autobiographie de la littérature aux médias. Paris: Seuil, 1980. 
Lejeune, Philippe. "Je ne suis pas une source: Entretien avec Philippe Artières." In Signes de vie, 115-137.

Lejeune, Philippe. "Journals of Exploration." In On Diary, 317-323.

Lejeune, Philippe. "L'autobiographie de ceux qui n'écrivent pas.” In Je est un autre, 229-316.

Lejeune, Philippe. "La cote Ln 27: pour une répertoire des autobiographies écrites en France au XIX ${ }^{\mathrm{e}}$ siecle." In Moi aussi, 249-272.

Lejeune, Philippe. "Les instituteurs du XIXe siècle racontent leur vie," Histoire de léducation, n 25 (janvier 1985), 53-104 (Répertoire des autobiographies écrites au XIXe siècle, Section 2, "Vies d'instituteurs," 83-104).

Lejeune, Philippe. Le Moi des demoiselles. Enquête sur le journal de jeune fille. Paris: Seuil, 1993.

Lejeune, Philippe. La Pratique du journal personnel. Enquête. Nanterre: Publidix, Université Paris-X, 1990.

Lejeune, Philippe. "Lire en sympathie." In Écrire sa vie, 49-65.

Lejeune, Philippe. "Lucullus Dines with Lucullus." In On Diary, 329-336; first published in Signes de vie, 215-227.

Lejeune, Philippe. Moi aussi. Paris: Seuil, 1986.

Lejeune, Philippe. On Autobiography, ed. with a foreword by Paul John Eakin, translated by Katherine Leary. Minneapolis: University of Minnesota Press, 1989.

Lejeune, Philippe. On Diary, ed. Jeremy D. Popkin \& Julie Rak, translated by Katherine Durnin (Honolulu, HI: University of Hawai'i Press, 2009).

Lejeune, Philippe. Signes de vie: Le pacte autobiographique 2. Paris: Éditions du Seuil, 2005.

Lejeune, Philippe. "The Story of a French Life-Writing Archive: 'Association pour l'autobiographie et le Patrimoine Autobiographique," Forum: Qualitative Social Research 12.3 , art. 7 (September 2011), www.qualitative-research.net/index.php/fqs/article/ view/1739/323 [accessed 3.2.18].

Lejeune, Philippe. "Tout lire." In Signes de vie, 183-200.

Lejeune, Xavier-Édouard. Calicot. Eds. and intro. Michel and Philippe Lejeune. Paris: Montalba, 1984.

Portelli, Alessandro. The Death of Luigi Trastulli and Other Stories: Form and Meaning in Oral History. Albany, NY: SUNY Press, 1991.

Rebreyend, Anne-Claire. Intimités amoureuses. France 1920-1975. Toulouse: Presses universitaires du Mirail, 2009.

Rioul, René. "La rhétorique de l'écho de lecture." Degrés: Revue de synthèse à orientation sémiologique vol. 36-37, nos 136-137 (2008-9): g1-g9.

Yeo, Stephen. A Useable Past: Volume 1: Victorian Agitator: Geoge Jacob Holyoake: Co-operation as "This new order of life." Brighton: Edward Everett Root, 2017.

\section{ABOUT THE AUTHOR}

T. G. Ashplant is a Visiting Professor at the Centre for Life-Writing Research, King's College London. He is a social and cultural historian, with a research interest in life writings as a source for exploring the construction and transformation of class and gender subjectivities, and their relationship to political identities. He has recently published "Life Writings from Below in Europe," History Workshop Journal no. 79 (spring 2015), 274-289; has co-edited (with Ann-Catrine Edlund and Anna Kuismin) Reading and Writing from Below: Exploring the Margins of Modernity (Umeå: Umeå University and Royal Skyttean Society, 2016); and has edited a special issue of the European Journal of Life-Writing on "Life Writing 'from 
Below' in Europe." He is author of Fractured Loyalties: Masculinity, Class and Politics in Britain, 1900-30 (London: Rivers Oram, 2007); and co-editor of Explorations in Cultural History (with Gerry Smyth; London: Pluto Press, 2001).

\section{NOTES}

All works cited in the notes, unless otherwise indicated, are by Philippe Lejeune.

1 "L'autobiographie de ceux qui n'écrivent pas," and "Autobiographie et histoire sociale;" published in English in On Autobiography (hereafter cited as $O A$ ), chs 9 (185-215: the first two of the three parts of the original; part 3, "Mémoire, dialogue, écriture: histoire d'un récit de vie," can be found in Je est un autre, 277-316) and 8 (163-184) respectively.

2 Of the success of this term, he has written: "I often feel less like a theoretician than like an adman who has hit the jackpot, for instance the man who invented La Vache qui rit."

3 "Definitions are made to be deconstructed": "Je ne suis pas une source," 116 (Here and below, unpublished translations from the French are mine).

4 Philippe's ironic humour is highlighted in Julia Watson's contribution to this festschrift.

5 On this early diary-keeping, see "Lucullus Dines with Lucullus." For its duration, and eventual resumption, On Diary, 29.

6 For the complex relations between his later private journal, and the published research journals, see "Journals of Exploration."

7 He has subsequently sketched those connections in a 2005 lecture, "From Autobiography to Life-Writing, from Academia to Association: A Scholar's Story." The quotation in note 2 above, and all unreferenced quotations here and subsequently, are from this (unpaginated) text, of which a French version is available as "Itinéraries d'une recherche."

8 Lejeune is not the only family member with a disposition towards life writing. He explores the complex meanings of his own involvement in writing family history, in "En famille." Philippe researched and edited his great-grandfather's unpublished autobiographical writings, with help of his own father Michel, in Xavier-Édouard Lejeune, Calicot; see also John Eakin's contribution to this festschrift. More recently, his work to produce a genetic analysis of the conversion of trench notebooks into the published First World War memoir of his mother's first cousin — and his own godfather-André Pézard uncovered a great mass of his ego-documents: "Du brouillon à l'oeuvre;" see further now "Genèse de Nous autres à Vauquois." "[W] hat benefit there is for all of us in the reconstruction of our family history: knowing as much as possible about where we come from. All the more so if one of your ancestors offers you his/her collaboration in this way. Here, furthermore, the practice of autobiographical writing was like the symbolic realization of a social promotion mediocrely achieved by the interested party, but well fulfilled in the next generation by his sons." $O A, 165$; cf. "En famille," 194.

9 "It seemed to me that the first job was to put together a serious and accurate investigation of autobiographical production in the nineteenth century, without prejudging conclusions that might be drawn from it." $O A, 164$.

10 "[T] he autobiographical act can have very different functions, which must not be artificially combined." $O A, 164$.

11 "Je ne suis pas une source," 118. In 1993, reflecting on his work on the hitherto neglected topic of young women's diaries, published as Le Moi des demoiselles, he noted: "Too often historians become interested in such documents only for the information they contain, neglecting the history of the writing practice itself. As for literary interpreters, they would seem to overlook texts of little value. When I talk about my research, I can see that people 
pity me. Some, worried, ask, 'But for you, where does literature stop?' For me, it never stops ..." On Diary, 141 (translation modified).

12 "Autobiographie et histoire sociale" (note 1 above) was followed by "Les instituteurs du XIXe siècle racontent leur vie;" "Crime et testament. Les autobiographies de criminels au XIXe siècle;" and "Autobiographie et homosexualité en France au XIXe siècle." For a fuller account of call number Ln 27, and the procedures Lejeune developed for exploring it, see "La cote Ln 27."

13 La Pratique du journal personnel; "Cher cahier ...;" Le Moi des demoiselles; "Cher écran ...."

14 Cf. "Je ne suis pas une source," 124-126.

15 The theme of Lejeune's democratic inclusiveness, in the spirit of 1968, is dealt with in detail in Jeremy Popkin's contribution to this festschrift.

16 "Itinéraries d'une recherche," 30-32; for earlier, fuller, accounts see "Tout lire," 192-200; "The Story of a French Life-Writing Archive."

17 Currently four: two in Paris, one each in Aix-en-Provence and Strasbourg.

18 Texts may also be donated subject to a period of embargo.

19 "Lire en sympathie", in Écrire sa vie, 49-65. Page references in this and the next paragraph are to this text.

20 Lejeune compares this experience to being in "a 'Balint group,' these groups of doctors who come together (observed by a psychoanalyst) to lay out in turn problematic clinical cases taken from their practice." "Lire en sympathie," 52-53.

21 " $[\mathrm{W}] \mathrm{e}$ try to give each text a chance, by stressing in our account its interesting or attractive aspects, while giving our future readers honest information on its contents and style. It's sometimes a balancing act, but what an isolated individual, such as myself could hardly achieve, becomes feasible for a group." "Story of a French Life-Writing Archive," para. 12. For another account of the practice of writing échos, see René Rioul, "La rhétorique de l'écho de lecture," who describes it as "a reconstruction of the text, along its lines of force" (g9).

22 See the striking examples in "Lire en sympathie," 58-61.

23 "Lire en sympathie," 61-62; cf . "Story of a French Life-Writing Archive," paras. 25-26.

24 For an analysis of the development of this archival tradition, see Ana Iuso, "The Role and Impact of the Archivi Della Scrittura Popolare." Lejeune also took inspiration from a slightly earlier French initiative to collect the writings of adolescents, see "Tout lire," 191.

25 "From the beginning, we have excluded the solution of an annual competition, which has its advantages and enhances the object of the competition, but requires engaging in a sort of 'last judgment' classifying lives and imposing, implicitly, standards." "Lire en sympathie," 51. For modification of his initial shock, see "Tout lire," 191-192: "The prize doesn't reward one text only: it values all the texts which are presented, and the genre itself."

26 "Lire en sympathie," 63, 64. He notes (63) as an exception Anne-Claire Rebreyend's Intimités amoureuses. France 1920-1975, based largely on 247 APA texts, which concerns itself with the history of expression as much as with the practices described. Cf. "Story of a French Life-Writing Archive," paras. 27-29.

27 "Yes, I have the soul of a collector, and a passion for inventories ... . It is the good fortune, and the role, of outsiders to try experiments." "Je ne suis pas une source," 116, 131. Cf. "Tout lire," 186: I appear to be a university teacher specialising in autobiography, but the reverse would be more true-I am an autobiographer, specialised in the university.

28 Psychoanalysis: "Je ne suis pas une source," 122, 124; cf. note 20 above. Sociology: "Itinéraries d'une recherche," 13-14. Ethnology: "Ethnologie et littérature." Oral history: Écrire sa vie, 24-25; "Je ne suis pas une source," 123-124.

29 "Je ne suis pas une source," 116-118, 125-133; "La cote Ln 27," 266-267; "Moi aussi," 258; "Journals of Exploration." 
30 Compare his comment on the reader's attitudes towards the model/hero and the ghostwriter of a ghost-written autobiography: "the model must take over the writing: the status as author is part of this value that the reader admires. Whether that writing is embodied by the intermediary of the pen of someone else is of little importance, since the reader has faith. 'Read, because this is my life.' What is important is the real presence of the body of Christ in the host. Of course, there is always a baker too, who has a hand in it. These comparisons, which are not meant to be disrespectful ...." (OA, 195-196) Bien sûr!

31 To cite two very different, but equally engaged examples: Alessandro Portelli's readings of the oral narratives of Italian Communist militants in The Death of Luigi Trastulli and Other Stories; and Stephen Yeo's presentation of the writings of a major nineteenth-century British Co-operator, A Useable Past: Volume 1: Victorian Agitator: Geoge Jacob Holyoake.

32 "If there is a misunderstanding or problem, the reader can, will have to, return to the group, who alone can validate the 'reading echoes' that we write and the exchanges of correspondence that we conduct in parallel with the depositors. To participate in a reading group .... it is an amazing psychological experience. After several years, we know each other straight off, by 'triangulation' so to speak (the texts, varied and numerous, help us 'situate' each other), we have a common memory of readings and discussions (sometimes disordered), with almost a folklore and a saga ... . The group is a place of trust and tranquility where we resolve all the alterations we would have to make to the key-principle of our activity: reading in sympathy." "Lire en sympathie," 52-53. 